\title{
ANALISIS IMPLIKATUR PERCAKAPAN DALAM NOVEL SIN KARYA FARADITA
}

\author{
Miranda Putri Ningtias \\ Universitas Pamulang \\ mirandaputri188@gmail.com
}

\begin{abstract}
Abstrak
Penelitian ini bertujuan untuk mendeskripsikan jenis implikatur percakapan beserta maksud implikatur percakapan yang terdapat dalam percakapan novel Sin karya faradita. Penelitian ini menggunakan metode deskriptif kualitatif dan sumber data dalam penelitian ini adalah percakapan dalam novel Sin karya Faradita. Data percakapan yang diperoleh dari novel Sin karya Faradita dari bab 1 sampai bab 13. Setelah data terkumpul lalu dikasifikasikan berdasarkan jenis implikatur percakapannya serta maksud implikatur pada novel Sin karya Faradita. Hasil penelitian yang dilakukan oleh penulis, penulis mendapatkan data jenis implikatur percakapan dalam novel Sin karya Faradita terdapat 54 data yang terbagi menjadi (1) beberapa jenis implikatur percakapan, diantaranya implikatur pecakapan jenis deklaratif dan sebanyak 4 data, jenis implikatur percakapan interogatif sebanyak 14 data, jenis implikatur percakapan imperatif sebanyak 18 data, juga jenis implikatur percakapan ekslamatif sebanyak 18 data. Selain itu juga terdapat (2) maksud implikatur percakapan pada novel, diantaranya yaitu maksud menyampaikan informasi, maksud menanyakan, maksud memerintah dan maksud menyatakan. Dari penelitian ini dapat disimpulkan bahwa jenis implikatur percakapan yang paling dominan adalah jenis implikatur percakapan imperatif dengan maksud memerintah dan jenis implikatur percakapan ekslamatif dengan maksud menyatakan, yakni sebanyak 18 data dengan presentase 33\%. Bahwa dalam novel Sin karya Faradita memperoleh banyak percakapan perintah dan seru juga terdapat maksud memerintah dan menyatakan. Hal ini dikarenakan novel ini memiliki tokoh utama wanita yang dominan aktif dan banyak memerintah tokoh utama laki-laki yang pendiam sehingga banyak ditemukan implikatur berjenis imperatif dan ekslamatif beserta maksud tuturannya yaitu memerintah dan menyatakan.
\end{abstract}

\section{PENDAHULUAN}

Seperti yang kita ketahui bahasa merupakan alat komunikasi yang digunakan oleh masyarakat berupa simbol-simbol bunyi yang dihasilkan oleh alat ucap manusia. Ilmu yang mempelajari bahasa disebut dengan istilah linguistik. Di dalam ilmu linguistik sendiri kita mengenal beberapa cabang dari ilmu linguistik. Secara umum kita mengenal linguistik mikro dan linguistik makro. Linguistik mikro berbicara mengenai internal bahasa itu sendiri, seperti fonologi, morfologi, sintaksis dan semantik. Sedangkan linguistik makro kita berbicara mengenai hal-hal diluar internal bahasa, seperti sosiolinguistik, pragmatik, psikolinguistik dan beberapa aspek lainnya.

Bahasa menjadi objek kajian linguistik mampu kita bandingkan menggunakan insiden-insiden alam yang sebagai objek kajian ilmu fisika; atau menggunakan aneka macam penyakit \& cara pengobatannya Yang sebagai objek kajian ilmu kedokteran; atau menggunakan tanda-tanda-tanda-tanda sosial pada rakyat Yang sebagai objek kajian sosiologi. Meskipun pada global keilmuan ternyata Yang merogoh bahasa menjadi objek kajiannya bukan hanya linguistik, tetapi linguistik permanen adalah ilmu Yang memperlakukan bahasa menjadi bahasa; sedangkan ilmu lain tidak demikian.

Bahasa yang ada pada novel baik berbentuk naratif, monolog, ataupun diskusi umumnya memiliki pesan yang mau di informasikan oleh pengarang. Oleh sebab itu, kalimat- kalimat yang ada pada novel terkadang memiliki iktikad tertentu yang mau di informasikan oleh pengarang kepada pembaca. Kalimat- kalimat yang 
memiliki arti tersirat tersebut di dalam ilmu bahasa diucap selaku implikatur. Salah satu novel yang di dalamnya tercantum kalimat- kalimat yang memiliki implikatur merupakan novel Sin.

Implikatur ialah sesuatu arti yang tersirat yang ada pada sesuatu tuturan. Suatu yang tersirat tersebut merupakan iktikad pembicaraan yang tidak diungkapkan melalui perkata yang sejelas- jelasnya oleh penutur. Implikatur dipecah jadi 2 ialah, implikatur konvensional serta implikatur konversasional( obrolan). Impilkatur konversasional merupakan implikatur yang ada dalam sesuatu obrolan, sebaliknya implikatur konvensional tidak wajib terjalin pada obrolan serta tidak bergantung pada konteks spesial buat menginterpretasikannya. Implikatur konvensional mempunyai watak yang berbeda dengan implikatur obrolan, ialah telah dikenal secara universal.

Riset ini diambil dengan menggukanan pendekatan pragmatik, pragmatik ialah cabang ilmu Linguistik yang terus menjadi diketahui pada masa saat ini ini meski pada kira- kira 2 dekade yang silam ilmu ini tidak sering diucap oleh pakar linguis. Perihal ini dilandasi oleh terus menjadi sadarnya para linguis kalau upaya mengungkap hakikat bahasa tidak hendak bawa hasil yang diharapkan tanpa disadari uraian terhadap pragmatik, ialah gimana bahasa itu digunakan dalam komunikasi. Kedatangan pragmatik cumalah sesi terakhir dari pertumbuhan linguistik yang berangsur- angsur, mulai dari disiplin ilmu yang menanganidata raga tuturan jadi disiplin ilmu yang sangat luas bersangkutan dengan wujud, arti serta konteks.

Definisi lain diungkapkan oleh Levinson (dalam Indriyani, 2017:2) bahwa mendefinisikan pragmatik sebagai berikut: Pragmatics is the study of those relations between language and context that are gramaticalized, or encode in the structure of language (Pragmatik merupakan kajian hubungan antra bahasa dan konteks yang tergramatikalisasi atau termodifikasi dalam struktur bahasa).

Dalam pendekatan ini terdapat beberapa disiplin ilmu, peneliti mengambil Implikatur sebagai acuan penelitian ini. Implikatur adalah sebuah makna yang tersirat dalam ungkapan lisan maupun wacana tertulis. Menurut Mey (dalam Indriyani, 2017: 2) implikatur berasal dari kata kerja to imply sedangkan kata bendanya adalah implication. Kata kerja ini berasal dari bahasa latin plicare yang berarti to flod "melipat", sehingga untuk mengerti apa yang dilipat dan disimpan tersebut haruslah dilakukan dengan cara membukanya. Dalam rangka memahami apa yang dimaksudkan oleh seorang penutur, lawan tutur haruslah selalu melakukan interpretasi pada tuturannya.

Berdasarkan penelitian yang penulis lakukan tentang Analisis Implikatur dalam Novel Sin karya Faradita berfungsi untuk mempermudah pemahaman komunikasi antar penulis dengan pembaca, agar maknanya dapat tersampaikan dengan baik. Alasan penulis memakai novel ini untuk penelitian karena terdapat bahasa dalam novel tersebut yang mengandung tuturan implikatur dan masih harus dikaji lebih dalam lagi.

Pada kesempatan kali ini, penulis ingin meneliti sebuah novel yang berjudul Sin, novel ini di karang oleh Faradita yang berkisah tentang kisah cinta seorang gadis remaja SMA yang bernama Ametta Rinjani dengan seorang laki-laki remaja teman sekolahnya bernama Raga Angkasa. Faradita dalam menuliskan novelnya banyak menggunakan tuturan yang mengandung implikatur. Contoh data yang mengandung implikatur konversasional (percakapan) dalam novel Sin karya faradita adalah sebagai berikut:

Rio : “Ada apa, Sayang? Apa yang kamu rasain?" 


\section{Metta : "Bajingan!!”}

Tuturan pada percakapan di atas merupakan implikatur percakapan interogatif. Tuturan tersebut tercermin ketika Rio menanyakan tentang keadaan Metta tetapi wanita itu malah mengumpat. Tuturan ini berbentuk implikatur interogatif, karena si penutur menuntut jawaban dari lawan tutur tetapi karena lawan tutur tengah merasakan sesuatu aneh terjadi pada dirinya, pertanyaan yang di berikan kepada penutur terdengar seperti ejekan. Hasilnya, lawan tutur tidak menjawab dengan nada halus juga menjabarkan keadaannya tetapi malah mengumpat. Dengan demikian, makna dari tuturan tersebut adalah si Penutur dalam percakapan diatas bernama Rio, bermaksud untuk menaklukan Metta sebagai Lawan tuturnya yang sangat sulit ia dekati, hingga akhirnya Rio memakai cara tidak terpuji dengan menaruh obat di minuman Metta.

\section{METODE PENELITIAN}

Tipe riset ini merupakan riset deskriptif kualitatif. Riset kualitatif merupakan riset yang meningkatkan penafsiran tentang orang serta peristiwa dengan mencermati konteks yang relevan. Riset kualitatif pula bersumber pada kenyataan yang terdapat, sehingga informasi yang dihasilkan ataupun dicatat berbentuk bahasa yang dapat dikatakan sifatnya semacam potret ataupun paparan seadanya. Riset kualitatif bertujuan buat menguasai fenomena sosial secara holistik serta menggali uraian lebih dalam serta lebih banyak. Watak informasi dari riset ini merupakan deskriptif, ialah mendeskripsikan hasil analisis dengan apa terdapatnya. Periset mengambil riset ini bertujuan buat mendeskripsikan implikatur konversasional ataupun obrolan yang terdapat pada novel Sin karya Faradita. Metode pengumpulan informasi yang digunakan pada riset ini memakai tata cara ikuti yang diwujudkan dengan metode sadap serta penulis memakai tata cara lanjutan ialah tata cara catat.

\section{HASIL DAN PEMBAHASAN}

Analisis data dalam penelitian berupa implikatur percakapan yang terkandung dalam novel Sin karya Faradita. Analisis dilakukan dengan mengklafikasikan implikatur percakapan kedalam empat jenis beserta maksud yang terkandung, yaitu deklaratif dengan maksud menyampaikan informasi, introgatif dengan maksud menanyakan, imperatif dengan maksud memerintah, dan ekslamatif dengan maksud menyatakan. Hal ini sesuai dengan permasalahan yang sudah dirumuskan oleh penulis. Berikut merupakan penjelasan implikatur percakapan.

Implikatur percakapan sangat bergantung kepada konteks terjadinya percakapan. Implikatur percakapan hanya muncul dalam suatu tindak percakapan (speech act). Oleh sebab itu, implikatur tersebut bersifat temporer (terjadi saat berlangsungnya tindak percakapan), dan non konvensional atau sesuatu yang diimplikasikan tidak mempunyai relasi langsung dengan tuturan yang diucapakan Levinson (dalam Diah Sukroni Zaidi, 2017: 6).

\section{Deklaratif}

Deklaratif atau yang bisa disebut juga sebagai kalimat berita adalah kalimat yang digunakan oleh pembicara untuk membuat pernyataan sehingga isinya merupakan berita bagi pendengar atau pembacanya, maksudnya: 
menyampaikan informasi kepada mitra tutur. Berikut merupakan implikatur percakapan deklaratif beserta maksudnya.

Menyampaikan informasi

Data 1

Raga : "Bawa sampah lo pulang. Lo bukan Cuma beli isinya tapi

bungkusnya juga"

Metta : "nanti juga ada yang bersihin. Buat itu mereka dibayar"

Raga: "selagi lo bisa bedain mana sampah mana yang enggak, harusnya

lo juga tau dimana tempat buangnya. Buat itu lo sekolah"

(Novel Sin Hal.

Tuturan pada percakapan di atas merupakan implikatur deklaratif. Tuturan tersebut tercermin ketika

Raga mengatakan "selagi lo bisa bedain mana sampah mana yang enggak, harusnya lo juga tau dimana tempat buangnya. Buat itu lo sekolah”. Efek yang ditimbulkan dari tuturan Raga adalah memberikan informasi kepada lawan tutur untuk membuang sampah pada tempatnya, yang merupakan kalimat berita yang dapat menginformasikan si lawan tutur tersebut. Tuturan diatas juga bermaksud implikatur menyampaikan informasi karena Raga menyuruh Metta untuk membuang sampah tetapi Metta tidak menggubrisnya, malah cenderung membantah. Jelas terlihat maksud tidak tersirat dari ucapan Raga diatas, yaitu membuat lawan tuturnya tidak membuang sampah secara sembarangan lagi karena seharusnya yang berpendidikan lebih paham soal ini.

2. Interogatif

Interogatif atau kalimat tanya adalah kalimat yang meminta kepada pendengar atau orang yang mendengar kalimat itu untuk memberi jawaban secara lisan. Kalimat interogatif berfungsi untuk menanyakan sesuatu, namun pada konteks tertentu dapat berupa kalimat perintah (perintah halus). Implikatur percakapan Interogatif terdapat pada data di bawah ini. Data yang telah diperoleh kemudian dianalisis seperti berikut.

Data 3

Data 3 berada pada halaman 11, dalam keadaan tokoh utama yaitu Metta sedang bersama sahabatnya yang bernama Lala di sebuah klub malam.

Lala : "Gak salah kan gue ngajak lo kesini?"

Metta : "Lo emang paling ngerti kesenangan gue, La"

Tuturan pada percakapan di atas merupakan implikatur percakapan Interogatif. Tuturan tersebut tercermin ketika Lala mengatakan "Gak salah kan gue ngajak lo kesini?" tuturan itu menuntut Metta untuk menjawab pertanyaannya serta menuntut pengakuan bahwa ia adalah sahabat yang sangat mengerti dirinya, karna lamanya persahabatan mereka. Bentuk ini, ditandai dengan kalimat yang diakhiri tanda tanya. Efek yang ditimbulkan dari tuturan tersebut adalah Metta tidak menjawab dengan jawaban Ya/Tidak, melainkan dengan apa yang sebenarnya ia rasakan. Karena mereka berdua sepakat bahwa klub malam adalah tempat paling menyenangkan bagi mereka berdua. Dengan demikian makna yang terkandung dalam tuturan tersebut adalah meminta si penutur untuk memberi jawaban secara lisan. Maka dari itu tuturan diatas bermaksud implikatur menanyakan. 
3. Imperatif

Tuturan pada novel SIN karya Faradita yang masuk ke dalam jenis implikatur percakapan imperatif ada pada data di bawah ini. Data yang telah diperoleh kemudian dianalisis seperti berikut.

Data 8

Data 8 berada pada halaman 21, terjadi ketika Metta dan Lala sedang berbicara di telpon.

Lala : "yee, main salahin ya lo sekarang. Lo aja yang sembarangan

nerima minuman. Gue kira lo malah udah pulang."

Metta : "Eh, bitch, jangan nelpon gue lama-lama. Belajar sono yang

rajin!"

Tuturan pada percakapan di atas merupakan implikatur percakapan Imperatif. Pada tuturan imperatif penutur mengharapkan lawan tutur untuk menanggapi pernyataan yang diberikan oleh si penutur, bisa berupa tindakan atau perbuatan lain yang diminta. Dalam tuturan di atas Metta menyuruh sahabatnya yang tengah berbicara untuk belajar, karena ia tahu pada saat itu adalah waktunya mereka belajar di sekolah. Pada tuturan diatas bermakna, Metta ingin menghindari pembicaraan dengan Lala, hasilnya ia memerintah Lala untuk belajar. Hal ini menjadikan tuturan diatas bermaksud memerintah.

4. Ekslamatif

Implikatur ekslamatif biasanya digunakan untuk menyatakan perasaan kagum atau heran. Secara formal kalimat ekslamatif ditandai dengan kata 'alangkah, betapa, bukan main' pada kalimat berpredikat adjektiva. Tuturan implikatur pada novel SIN karya Faradita yang masuk ke dalam kategori tuturan ekslamatif ada pada data di bawah ini. Data yang telah diperoleh kemudian dianalisis seperti berikut.

Data 13

Data 13 berada pada halaman 29, ketika Raga sedang berada di sekolah, tiba-tiba Metta menghampirinya meminta Raga untuk mengatakan maaf kepadanya.

Metta : "lo ninggalin gue terikat di ranjang. Tau gak semalu apa rasanya ? seumur hidup gue ga bisa lagi datang ke sana. Lo pikir gue harus ngasih penghargaan untuk itu?"

Raga : "seharusnya gue tau kalo nolongin lo itu percuma."

Tuturan pada percakapan di atas merupakan implikatur percakapan Ekslamatif. Di lihat dari pengertiannya, tuturan ekslamatif adalah tuturan yang digunakan untuk menyatakan sebuah perasaan. Yang di ucapkan oleh Raga pada tuturan diatas adalah perasaan kecewa yang muncul karna ia menolong gadis itu. Maknanya, tuturan yang Raga ungkapkan adalah perasaan yang sebenarnya ia rasakan pada saat itu, padahal ia sudah berbaik hati untuk menolong Metta yang tengah di pengaruhi obat pada malam itu, tetapi Metta malah menghampirinya dan menyuruh Raga untuk meminta maaf padanya. Tuturan diatas bermaksud implikatur menyatakan/mengungkapkan. 


\section{KESIMPULAN}

Berdasarkan hasil penelitian dan pembahasan mengenai implikatur percakapan dalam novel Sin karya Faradita dapat diambil kesimpulan terdapat implikatur percakapan dan maksud dari implikaturnya berupa 1) deklaratif 2) interogatif 3) imperatif dan 4) ekslamatif.

Dari penelitian yang dilakukan oleh penulis, penulis mendapatkan data jenis implikatur percakapan dalam novel Sin karya Faradita terdapat 54 data yang terbagi menjadi beberapa jenis diantaranya implikatur jenis deklaratif dan maksud implikaturnya ditemukan sebanyak 4 data, jenis implikatur interogatif dan maksudnya sebanyak 14 data, jenis implikatur imperatif dan maksudnya sebanyak 18 data juga jenis implikatur ekslamatif dan maksudnya sebanyak 18 data. Dapat di lihat hasil temuan data yang tercatat dalam presentase penelitian novel Sin karya Faradita total jenis implikatur percakapan beserta maksud implikatur pada percakapan dalam novel sebanyak $100 \%$ data yang terbagi menjadi deklaratif $8 \%$, interogatif $26 \%$, imperatif $33 \%$, ekslamatif $33 \%$.

Dari penelitian ini dapat disimpulkan bahwa jenis implikatur percakapan yang paling dominan adalah jenis implikatur imperatif dan ekslamatif beserta maksudnya, yakni sebanyak 18 data dengan presentase 33\%. Bahwa dalam novel Sin karya Faradita memperoleh banyak percakapan perintah dan seru. Hal ini dikarenakan novel ini memiliki tokoh utama wanita yang dominan aktif dan banyak memerintah tokoh utama laki-laki yang pendiam sehingga banyak ditemukan implikatur berjenis imperatif dan ekslamatif beserta maksudnya.

\section{DAFTAR PUSTAKA}

Budiwati, T. R. (2017). Kesantunan berbahasa mahasiswa dalam berinteraksi dengan dosen di Universitas Ahmad Dahlan: analisis pragmatik. The 5TH Flurecol Proceeding, UAD, Yogyakarta, 557-571.

Muhammad. 2014. Metode Penelitian Bahasa. Jogjakarta: Ar-Ruzz Media.

Putu, Dewa dan I. Wijana. 1996. Dasar-dasar Pragmatik. Yogyakarta : Andi

Suhardi. 2013. Linguistik Umum. Jogjakarta : Ar-Ruzz Media.

Surastisna. 2011. Pengantar Semantik dan Pragmatik. Yogyakarta: New Elmerta

Yusri. 2016. Ilmu Pragmatik dalam Prespektif Kesopanan Bahasa. Yogyakarta : Deepublish.

Zaim, Muhammad. 2014. Metode Penelitian Bahasa : Pendekatan Struktural. Padang : Sukabina Press.

\section{Jurnal}

Haliko, M. K. (2017). Implikatur percakapan dalam talk show hitam putih di trans 7. Bahasa dan sastra, 2(1).

Handayani, C., Sumarwati, S., \& Suhita, R. (2014). Implikatur Percakapan Dalam Acara Talk Show Mata Najwa Di Metro TV. BASASTRA, 2(3).

Indriyani. 2017. "Implikatur Percakapan dalam Novel Daun yang Jatuh tak pernah membenci angin karya Tere Liye". Universitas Pamulang.

Maendela, Via. 2018. "Pelanggaran Prinsip Kerjasama dan Implikatur Percakapan pada Sinetron L.O.L Len on Len taksi". Universitas Pamulang.

Sukroni Zaidi, Diah. 2013. "Implikatur Percakapan dalam Novel Puspitasari Prawan Bali karya Any Asmara (Kajian Wacana)" . Universitas Negri Yogyakarta. https://eprints.uny.ac.id/44412/1/Diah\%20Sukron\%20Zaidi 08205241055.PDF (di akses pada tanggal 14 September 2020) 